
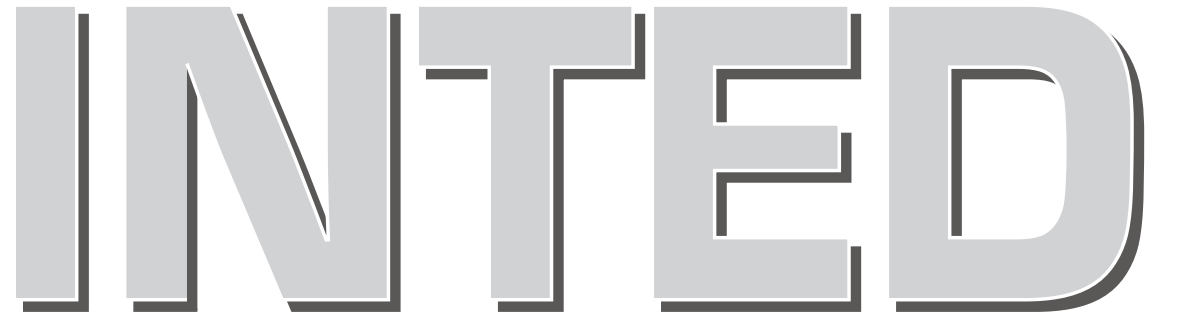

\section{1}

15th International

Technology, Education and

Development Conference

8-9 March, 2021

\section{CONFERENCE PROCEEDINGS}


Published by

IATED Academy

iated.org

INTED2021 Proceedings

15th International Technology, Education and Development Conference

March 8th-9th, 2021

\section{Edited by}

L. Gómez Chova, A. López Martínez, I. Candel Torres

IATED Academy

ISBN: 978-84-09-27666-0

ISSN: $2340-1079$

DL: V-370-2021

Book cover designed by

J.L. Bernat

All rights reserved. Copyright (C) 2021, IATED

The papers published in these proceedings reflect the views only of the authors. The publisher cannot be held responsible for the validity or use of the information therein contained. 


\title{
LEARNING EXCHANGE: A COLLABORATIVE WORK BETWEEN COURSE UNITS
}

\author{
F. Silva, J.E. Ribeiro, P.M. Barros \\ Instituto Politécnico de Bragança (PORTUGAL)
}

\begin{abstract}
The joint reflection between teachers from different areas, and with different backgrounds, on the strategies to be implemented in some course units, with the aim of building a scenario that fosters learning and, in parallel, allows the development of transversal skills, led to the idealization of a teaching proposal in which, in addition to valuing learning in a real work context, it was intended to promote the exchange of knowledge acquired by the students from different course units.
\end{abstract}

The proposal in question involved the course units of Mechanical Technology I and Manufacturing Processes I, of the 2nd year of the Bachelor in Mechanical Engineering and in Technology and Industrial Management, respectively, and the course unit of Safety and Environment of the 1th year of the Higher Professional Technical Course in Mechanical Technology and Vehicles.

Summing up, in addition to two study visits to companies in the field of metallomechanics, there was an exchange of knowledge between students. In this context, undergraduate students were given the role of conducting communication sessions that would clarify some of the mechanical processes observed in companies. Similarly, to the students of the Higher Professional Technical Course were tasked with sharing about the hazards and risks inherent in the real work context in the visited companies and the respective awareness of the means of protection to be used.

The analysis and evaluation of the experience carried out was based on the observations of the teachers of the classes, in the productions developed by the students, in the intermediate questionnaires that were carried out after the visits, more directed to the expectations and learning carried out and, in a final questionnaire, in which students were asked for their opinion on various aspects related to the developed experience. In this sense, in addition to describing the project carried out, it is intended to focus on some of the opinions/perceptions of teachers and students involved about the contribution of the experience to the promotion of learning.

Keywords: Knowledge sharing, work context, higher education, mechanics, safety.

\section{INTRODUCTION}

The higher education teacher, in addition to being concerned with the scientific domain of the contents he works with his students, must also be aware of what is happening in terms of the learning environment related to the course units (UCs) that he teaches. The learning should be centred on the student's ability, motivating individual and cooperative work in order to develop fundamental transversal skills, such as the ability to work in team [1]. It is very important that the student experiences difficulties in environments as close as possible to the professional reality of the course he attends, as stated by Mendes [2] "training in the context of a company represents an asset for learning because it allows the contextualization of theoretical knowledge and practical directly in the work environment, facing specific challenges to the specificity of each activity" ( $p$. iv). Corroborating this idea, Silva, Barros and Ribeiro ([3], [4]) conclude, based on the experiences with students of the Higher Professional Technical Courses (CTeSP), that by promoting learning with a strong connection to practice, namely to the laboratory context, there is evidence of a positive impact on student learning. They also found that the knowledge acquired during the execution of tasks can be useful for other UCs.

Collaborative work between teachers from different areas and with different backgrounds, by promoting the debate on teaching and assessment practices, can boost the implementation of some more student-centred practices, with results considered favourable from a motivational and of learning point of view (e.g. [3], [4], [5], [6], [7], [8]). Continuing this dynamic of collaboration, the authors decided that it would be productive to extend it to the students themselves, as the exchange of knowledge between students could result in enriching learning for all involved. The combination of this aspect with the previously conveyed idea of the importance of connection to the work context, was the 
basis of the ideology of a teaching experience that was carried out with students from the Bachelor courses in Mechanical Engineering, in Technology and Industrial Management and CTeSP in Mechanical Technology and Vehicles at a higher education institution in northern Portugal. More specifically, the experience carried out had as main objectives:

- Promote the improvement of student's learning;

- Guide classes in a way so that the student has a more active role in their learning;

- Motivate the students to engage in the construction of their own knowledge;

- Contribute so that CTeSP students have a more informed view on aspects related to the practice of the Mechanical Engineering course;

- Establish a greater connection between courses and the business world/professional context;

- Promote a more contextualized learning of the contents;

- Promote the development of transversal skills, such as organization and communication, teamwork, critical thinking and sharing with peers.

In this paper, we intend to describe the project carried out and, based on the opinions/perceptions of teachers and students involved in the process, make an analysis of its contribution to improving students' learning.

\section{METHODOLOGY}

In the following sub-points, it is presented a contextualization of the environment in which the experience described occurred and is indicated the research methodology adopted, with regard to the database collection and analysis.

\subsection{Study context}

The proposal in question involved the Mechanical Technology I and Manufacturing Process I UCs, on the 2nd year of the Bachelor courses in Mechanical Engineering and in Technology and Industrial Management, respectively, and the Safety and Environment UC on the 1st year of the CTeSP in Mechanical Technology and Vehicles. The UCs of Mechanical Technology I and Manufacturing Processes I are taught together, being the fundamental contents processes of casting manufacturing and processes of metal plastic deformation manufacturing. The UC Safety and Environment covers the contents: legislation, prevention management, assessment and control of occupational risks, hygiene and safety at work and environmental management.

The project involved two study visits made with students to companies in the field of metallomechanics: "Fundição do Alto da Lixa" and "MAutomotive Portugal, Unipessoal Lda.". In addition, knowledge exchange sessions were held between undergraduate and CTeSP students. Thus, undergraduate students held two communication sessions in order to clarify the mechanical processes used in companies and CTeSP students held a session in which they shared their view on the hazards and risks inherent to the real work context in the companies visited and sensitized the colleagues to the means of protection to use.

The CTeSP students would benefit if, previously, they had knowledge of some manufacturing processes in the machining area, as well as the operation of the machines, therefore an exchange with the students of the Mechanical Engineering/Technology and Industrial Management courses would make perfect sense. Students will also have an idea of the work context of a mechanical engineer, if they choose to follow this profession.

On the other hand, as not all students in the Mechanical Engineering or Technology and Industrial Management courses have knowledge in the area of Safety and Hygiene at Work, they may not be aware of the safety procedures that are imposed with a certain type of industrial machinery. Thus, it is considered that it will be beneficial for them to attend the presentation sessions on the topic carried out by the students of CTeSP, allowing them to be alerted to aspects that may be useful to them in their professional future. The construction of the presentations made in the sessions was carried out in group, with the support of the teachers of each course unit.

Table 1 presents a summary of the activities developed in the three courses. 
Table 1. Summary of activities performed and schedule.

\begin{tabular}{|c|c|c|}
\hline $\begin{array}{l}\text { Week } \\
\text { of } \\
\text { classes }\end{array}$ & Safety and Environment & $\begin{array}{l}\text { Mechanical Technology I (Bachelor in Mechanical } \\
\text { Engineering) } \\
\text { Manufacturing Processes I (Bachelor in Technology } \\
\text { and Industrial Management ) }\end{array}$ \\
\hline $1-5$ & $\begin{array}{l}\text { Work on the theme of Safety and Hygiene } \\
\text { at Work. }\end{array}$ & $\begin{array}{l}\text { Research by students of various casting processes. } \\
\text { Weekly meeting on the evolution of the research } \\
\text { carried out and definition of strategies and paths to } \\
\text { be followed at work. } \\
\text { Preparation of PowerPoint presentations. }\end{array}$ \\
\hline 6 & \multicolumn{2}{|c|}{$\begin{array}{l}\text { Communications session about "Casting processes". } \\
\text { Speakers: Students of Mechanical Technology I/Manufacturing Processes I. } \\
\text { Participants: Students from both courses. }\end{array}$} \\
\hline & \multicolumn{2}{|c|}{ Study visit: Joint visit to the company "Fundição do Alto da Lixa". } \\
\hline $7-8$ & $\begin{array}{l}\text { Objective: Risk analysis related to the } \\
\text { manufacturing process of sand casting. }\end{array}$ & $\begin{array}{l}\text { Objective: to experience in a real context the } \\
\text { manufacturing process of sand casting. } \\
\text { Visit report. }\end{array}$ \\
\hline $9-11$ & $\begin{array}{l}\text { Risk analysis. } \\
\text { Risk assessment. } \\
\text { Preventive measures. } \\
\text { Work on the Environment theme. }\end{array}$ & $\begin{array}{l}\text { Research by students of processes of metal forming } \\
\text { processes, sheet metal cutting and stamping. } \\
\text { Weekly meeting on the evolution of the research } \\
\text { carried out and definition of strategies and paths to } \\
\text { be followed at work. } \\
\text { Preparation of PowerPoint presentations. }\end{array}$ \\
\hline & \multicolumn{2}{|c|}{ Study visit: Joint visit to the company "MAutomotive Portugal, Unipessoal Lda." in Bragança. } \\
\hline 12 & $\begin{array}{l}\text { Objective: Risk analysis related to the } \\
\text { manufacturing process of sheet metal } \\
\text { forming and metal cutting. }\end{array}$ & $\begin{array}{l}\text { Objective: to experience in a real context the } \\
\text { manufacturing process of sheet metal forming and } \\
\text { metal cutting. }\end{array}$ \\
\hline 13 & \multicolumn{2}{|c|}{$\begin{array}{l}\text { Communications session about "Metal forming processes, sheet metal cutting and stamping". } \\
\text { Speakers: Students of Mechanical Technology I/Manufacturing Processes I. } \\
\text { Participants: Students from both courses. }\end{array}$} \\
\hline 14 & $\begin{array}{l}\text { Risk analysis. } \\
\text { Risk assessment. } \\
\text { Preventive measures. } \\
\text { Preparation of a PowerPoint presentation } \\
\text { on the work done. }\end{array}$ & Visit report. \\
\hline 15 & \multicolumn{2}{|c|}{$\begin{array}{l}\text { Communications session about "Hazards and Risks in real context". } \\
\text { Speakers: Students of Safety and Environment. } \\
\text { Participants: Students from both courses. }\end{array}$} \\
\hline
\end{tabular}

These activities underwent some adjustments in relation to the initial plan, due to some contingencies related to operational and logistical aspects, some of them due to the availability of companies to receive students. Thus, the study visits initially planned to occur after the undergraduate students' communication sessions, were carried out one after the communication session and the other before the communication session. Aspect that, although not foreseen, served to listen to students about the methodology that seemed most productive for their learning.

The evaluation of students in the UCs was carried out according to the nature of the tasks proposed to students. In addition to valuing knowledge about contents, active and responsible participation in tasks was taken into account and, in the case of presentations, the ability to synthesize, select, organize and structure information, as well as the ability to communicate and expose work content. 


\subsection{Methods of database collection and analysis}

The evaluation of the experience is based on the observations made by the class teachers (condition of participant observer) throughout the process, on the students' productions, on the intermediate questionnaires that were carried out after the study visits, more focused on the expectations and learning carried out and, in a final questionnaire, asking students for their opinion on several aspects that had to do with the experience developed.

The final questionnaire applied to undergraduate and CTeSP students was divided into two parts. In the first part of the "General information", general and personal information were requested at academic and personal level. In the second part of "Information related to the course unit", it was intended to know the students' opinions about: UC classes; the study visits made and how they were enriching for learning and communication sessions conducted by colleagues.

In most closed answers, students expressed their opinion on several items, based on a Likert scale with four levels: 1 - Strongly disagree; 2 - Disagree; 3 - Agree and 4 - Totally agree.

In the data analysis of the questionnaire, for the case of closed answers, were used descriptive statistics techniques, namely the calculation of frequencies organized in tables as a way to structure and synthesize the information. Posteriorly, based on the open student's answers, were defined categories. In the case of open answer questions, were defined categories, posteriorly, from the students' answers.

\section{RESULTS}

\subsection{Students presentations}

The communications sessions on "Casting processes" and "Metal forming processes, sheet metal cutting and stamping", who had as speakers the students from Mechanical Technology I/Manufacturing Processes I, as well as the communication session on "Hazards and Risks in real context" whose speakers were Safety and Environment students, took place in the institution's auditoriums. Figure 1 shows moments of the presentations carried out.

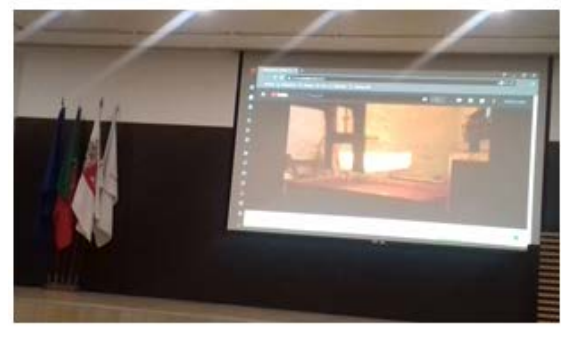

(a)

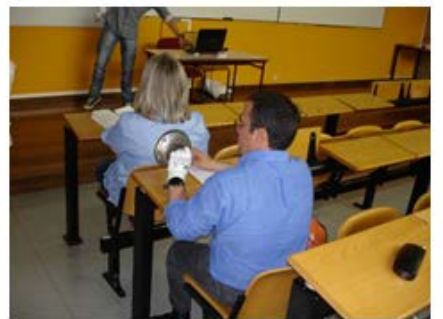

(b)

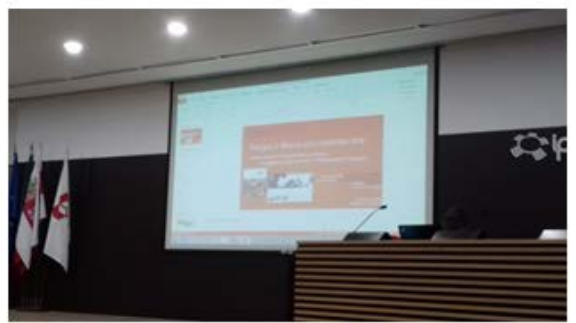

(c)

Figure 1. Students presentations on communications sessions about: (a) "Casting processes", (b) "Metal forming processes, sheet metal cutting and stamping" and (c) "Hazards and risks in real context".

\subsection{Opinion about the presentations and knowledge exchange}

Most undergraduate students believe that the presentation of the work has improved their ability to argue ( $86.5 \%$ of the students agree or totally agree) and exposure to a different audience has allowed them to work on communication skills $(86.5 \%$ of students agree or totally agree). The biggest difficulty pointed out $(48.6 \%$ agree or totally agree) was the fact that they must to simplify the presentation so that the colleagues of CTeSP understood.

Likewise, CTeSP students, who represented their colleagues in the presentation session, agree or totally agree $(83.3 \%)$ that this allowed them to improve their communication skills. Despite considering that they had difficulties in exposing their work ( $66.7 \%$ agree or totally agree), they consider that, even so, it was more gratifying to do it for their undergraduate colleagues than just for your course colleagues (66.7\% agree or totally agree).

In general, it can be considered that the presentations of CTeSP students, about aspects related to safety at work, were enriching for undergraduate students. It should be noted that $89.2 \%$ of 
undergraduate students consider that the information transmitted alerts them to some precautions they must take in terms of safety when working in laboratories or, in the future, in industrial environments.

Most of CTeSP students recognize the usefulness of communication sessions, carried out by colleagues from undergraduate courses, to acquire new knowledge in the field of mechanics, however the disadvantage (pointed out by $70 \%$ of students) is the excessive time that these sessions had. Therefore, this should be an aspect to be taken into account in future experiences.

It is also emphasized that it would be pertinent in this type of presentations to promote an increase in the dialogue between the presenters and the attendance, since only $32.4 \%$ of the undergraduate students claim to have actively participated in the session by asking questions and in the case of CTeSP students, this percentage varies between $21.1 \%$ (session on "Casting processes") and $31.3 \%$ (session on "Metal forming processes, sheet metal cutting and stamping").

\subsection{Opinion about the study visits}

As for study visits, both undergraduate and CTeSP students, who answered the final questionnaire, expressed a very positive opinion about their contribution to their learning (see Fig. 2).

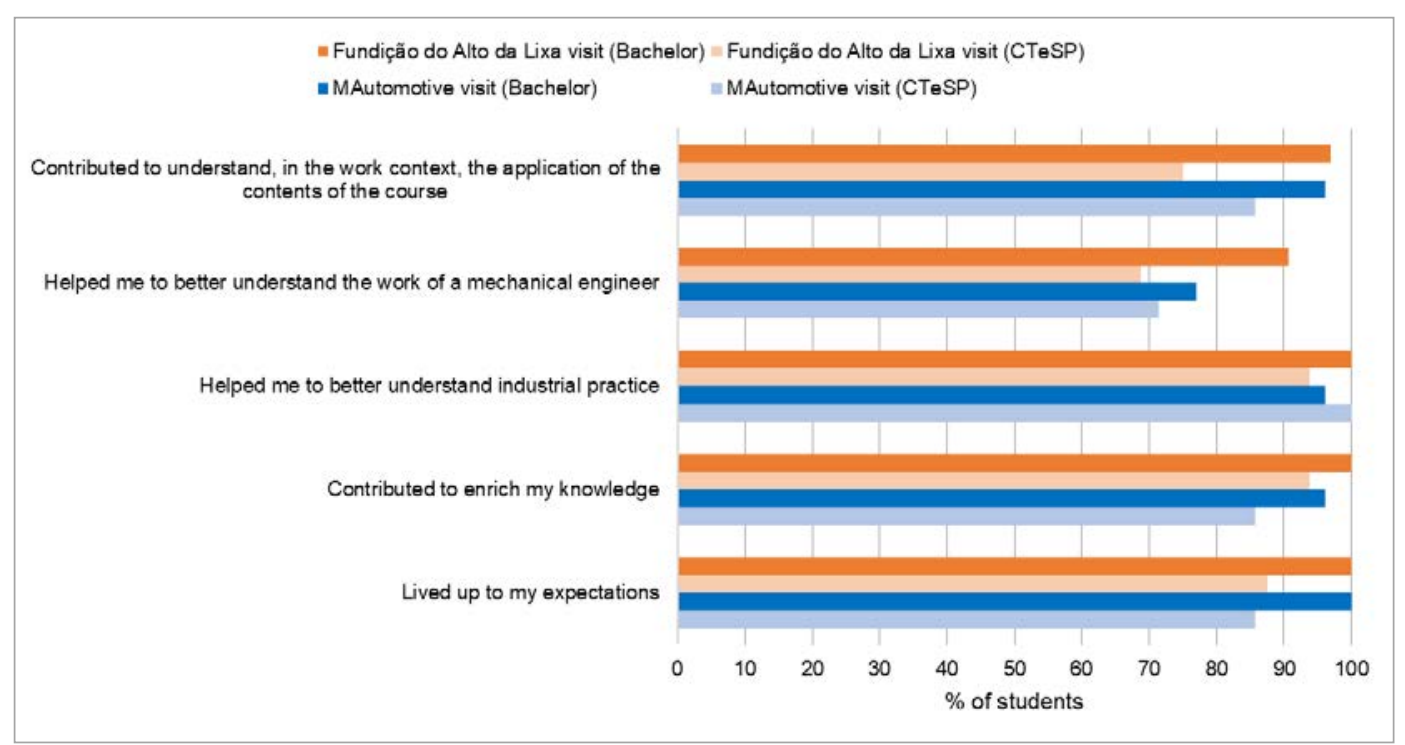

Figure 2. Percentage of students that agree or totally agree with the referred items.

This evaluation is in accordance with the aspects mentioned by the undergraduate students in the intermediary questionnaires of the study visits. For example, commenting on whether the visit to the company "Fundição do Alto da Lixa" met your expectations, there are students who mention:

"Yes. Because it was undoubtedly an enriching visit at all levels, as I got to know a little about the entire casting process that takes place there, having seen all the stages that the casting process goes through. I also had the opportunity to see repair components for agricultural and earthmoving machinery (...)."

"Yes, the realization of the study visit complemented what was discussed in the theoretical classes. (...) It made us acquire other knowledge and a different perspective of the foundry."

"Yes. This type of visits to work structures is always an asset for us, as our contact with the world of work is in general very scarce. (...) In practice, being able to see how things really work at the factory, cooperation between the various sectors, seeing the real size of things, smelling, is always very good."

In the case of the MAutomotive company, the students' comments also convey that they considered the visit advantageous for their learning:

"The visit was very beneficial, as it allowed for assimilation and a better understanding of the concepts covered in the course unit." 
"Yes, the visit lived up to my expectations, since it was possible to observe in real context all the processes of forming the sheet and the different stages of manufacture."

"(...) The issues raised were clear. In my opinion it was an excellent initiative that can lead to creating ideas and expectations about the future of an engineer."

The advantages of the study visits are also evidenced in the comments of CTeSP students in the intermediate questionnaires. For example, some students who comment on their impressions about the visit to the company "Fundição do Alto da Lixa" refer to:

"The visit lived up to my expectations because it was very interesting to understand the functioning of a company of this dimension and to understand/be able to analyse safety in that same place."

"With the visit, I consider that I acquired an intensive knowledge about all the safety procedures used by the workers, with particular interest in the protective mask with gold leaf, due to the radiation emitted by the molten material."

"Yes, no doubt, being able to face reality is something else, and the fact of analysing the hazards and risks of the place makes learning more interesting."

Likewise, in the case of MAutomotive, student comments also highlight the benefits of visiting for their learning:

"Yes, because it gave us a better idea of how a factory works and how the machines and all the work they involve really work."

"I was able to learn what precautions to take on the different machines."

"I was able to observe in practice the contents taught in the classroom related to Safety and Hygiene at Work."

\section{CONCLUSIONS}

We concluded that the experience developed had positive effects on students' learning. The study visits were enriching in that they made it possible to learn about the working methods of companies linked to the mechanical sector and observe the manufacturing processes in a real context. This fact also contributed for the students of CTeSP to become aware of the type of work that a mechanical engineer can do, if they want to pursue studies in this area. In addition, they had the opportunity to observe in a factory context the hazards underlying certain activities, which allowed them to work significantly on the contents inherent to the Safety and Environment UC that they attended, as well as to acquire a greater awareness of these aspects.

The presentation to other audiences and all the conditions related to their preparation promoted the development of transversal skills, such as the ability to work as a team, select materials and synthesize information, communicate and deepen the knowledge of technological means. It is recognized, however, that the sessions held by undergraduate students can make the communication process more complex, as they cover very specific knowledge of a given domain. In this sense, the conclusions that can be drawn from this experience are that, mainly, in these sessions one should always try to adapt the technical language to the target audience, its duration cannot be excessive and, whenever possible, must be used explanatory images or "real objects" of the work context to accompany the explanations.

\section{REFERENCES}

[1] A. Ramos, F. Delgado, P. Afonso, A. Cruchinho, P. Pereira, P. Sapeta and G. Ramos, "Implementação de novas práticas pedagógicas no ensino superior", Revista Portuguesa de Educação, vol. 26, no. 1, pp. 115-141, 2013.

[2] J. Mendes, O papel da formação em Segurança e Saúde no Trabalho no desenvolvimento de competências profissionais: estudo de caso (Dissertação de Mestrado). Setúbal/Portugal: Instituto Politécnico de Setúbal, 2015. 
[3] F. Silva, P.M. Barros and J.E. Ribeiro, "Hazards and risks of machine-tools: an experience in the mechanical technology and vehicles course," in ICERI2018 - 11th International Conference of Education, Research and Innovation (L. G. Chova, A.L. Martínez and I.C. Torres, eds.), pp. 62606266, Sevilha/Espanha: IATED Academy, 2018.

[4] F. Silva, P.M. Barros and J.E. Ribeiro, "Aprender segurança e higiene: e se o nosso cenário de aula for o laboratório?," in Relatos e investigação de práticas de ensino de Ciências e Tecnologia - Atas do Encontro internacional "A Voz dos Professores de C\&T" (VPCT 2018) (J.B. Lopes, J.P. Cravino and C. Costa, eds.), pp. 249-254, Vila Real/Portugal: Universidade de Trás-os-Montes e Alto Douro, 2018.

[5] J.E. Ribeiro, P.M. Barros and F. Silva, "Promote learning in mechanical technology manufacturing work equipment," in ICERI2018 - 11th International Conference of Education, Research and Innovation (L. G. Chova, A.L. Martínez, I.C. Torres eds.), pp. 6278-6283, Sevilha/Espanha: IATED Academy, 2018.

[6] J.E. Ribeiro, P.M. Barros and F. Silva, "Uma experiência de integração da teoria com a prática em tecnologia mecânica II," in Relatos e investigação de práticas de ensino de Ciências e Tecnologia - Atas do Encontro internacional "A Voz dos Professores de C\&T" (VPCT 2018) (J.B. Lopes, J.P. Cravino and C. Costa eds.), pp. 240-248. Vila Real/Portugal: Universidade de Trás-os-Montes e Alto Douro, 2018.

[7] J.E. Ribeiro, P.M. Barros and F. Silva, "Active methodology in mechanical technology," in EDULEARN 18 - 10th International Conference on Education and New Learning Technologies (L. G. Chova, A.L. Martínez and I.C. Torres, eds.), pp. 6870-6875, Palma de Maiorca/Espanha: IATED Academy, 2018.

[8] J.E. Ribeiro and P.M. Barros, "Agora sou eu a expor o tema - abordagem alternativa em Tecnologia Mecânica," in CNaPPES 2017 - Congresso Nacional de Práticas Pedagógicas no Ensino Superior (F. Almeida, F. Remião, J.F. Oliveira, L. Castro, M.A. Ferreira, P.R. Pinto, P. Neto and R. Cadima, eds.), pp. 181-186, Setúbal/Portugal: Instituto Politécnico de Setúbal, 2017. 